\title{
1. Introduction to the Research Handbook on Communicating Climate Change
}

\author{
David C Holmes
}

\section{COMMUNICATING THE ANTHROPOCENE}

Communicating climate change in the twenty-first century has never been more pressing. The science is in, the solutions known, but the communication is not nearly adequate to the gravity of the issue, and current emissions pathways are rapidly hurtling towards a climate ever more dangerous for humans and millions of species that are already being affected.

Scientists know enough about climate change to advise politicians and policy makers of the scale of the problem and its solutions. The science informs global processes of arriving at climate policy recommendations by groups such as the Intergovernmental Panel on Climate Change (IPCC) and the United Nations Framework Convention on Climate Change (UNFCCC).

But for many outside the most vulnerable regions, such as equatorial and small island nations, climate change is seen to be distant in space and time, even in countries with strong public interest journalism and investigative reporting. For them, most of the processes of climate change are not available to the senses, and few understand the nature of climate sensitivity - where just a small change in global average temperature, caused by heat-trapping gases from human activity, can rapidly lead to a climate that is incompatible with human settlement and an unsuitable habitat for nearly all living things.

The globalization of consumer culture, and the energy-intensive infrastructure that it requires, has emancipated much of the developed world from the direct compulsion of need. But this has only been made possible by the exploitation of nature through fossil fuel energy sources that have super-charged the industrial forces of production. Or, as climate columnist George Monbiot has put it, today: 'We inhabit the brief historical interlude between ecological constraint and ecological catastrophe' (Monbiot 2006, p. 6).

As a result of these industrial activities, humans have emitted greenhouse gases in concentrations that are changing the climate at 170 times the natural rate. What once took 8500 years to happen now takes only 50. With industrialization, the world of the Holocene - the 10000 years of relatively stable climate that allowed human civilization to develop - has abruptly ended. Rather, we now live in the 'Anthropocene', where greenhouse emissions are effectively a geo-engineering of the Earth's atmosphere, adding a dangerous amount of energy into the climate system and committing the Earth to hundreds of years of extreme climate impacts. 


\section{COMMUNICATING CLIMATE CHANGE: BETWEEN SCIENCE AND POLITICS}

Reflecting on climate change communication research and practice in the second decade of the twenty-first century, Susanne Moser observes that climate communication research is 'highly distributed across sectors and disciplines', rather than confined to the discipline of communication (Moser 2016). As shown in this Handbook and elsewhere, psychology is also an important domain (Shome \& Marx 2009; Van der Linden et al. 2015a). But what also stands out as supervening contexts of climate change communication are the fields of science and politics.

In the 'discovery' phases of climate science, scientists were almost exclusively the only communicators, and were simply reporting their findings. The first scientist to discover that an increase in carbon dioxide $\left(\mathrm{CO}_{2}\right)$ corresponded to a warmer atmosphere was Eunice Foote, whose work was presented by the Secretary of the Smithsonian Institute, Joseph Henry, to the American Association for Advancement of Science in Albany, USA in 1856 (Wicks 2020). This was followed by Irish physicist John Tyndall in 1859, who is credited with uncovering the specific action of $\mathrm{CO}_{2}$, identified as a heat-trapping blanket known today as the 'greenhouse effect'. He communicated this in his Bakerian Lecture, read to the Royal Society of London in 1861 (Tyndall 1861).

Since then, tens of thousands of climate scientists - oceanographers, glaciologists, paleo-climatologists, atmospheric chemists, tropical meteorologists, to name a few specializations - have reported their findings in papers which, when added together, address the global extent of climate change.

Remarkably, these specializations rarely speak to each other, and it is only international government bodies, such the IPCC and the UNFCCC, that have brought them together, thus making the overall science much clearer. It also makes the 97 per cent consensus that climate scientists have on human-caused climate change, all the more remarkable. (For a review of consensus studies, see Cook et al. 2016.)

A global turning point for the influence of climate science on policy was a scorching day in Washington, DC in June 1988. James Hansen, Director of NASA's Goddard Space Studies Institute, gave testimony to the Energy and Natural Resources Committee of the US Senate, asserting that globally 1988 was 'warmer than at any time in the history of instrumental measurements' and that 'there was only a $1 \%$ chance that this effect was not caused by human activity' (Sheppard 2008).

The next morning, the New York Times led with the headline, 'Global warming has begun', a story that resounded throughout the world's newswires. What was unique about this moment was that most categories of crisis coverage are short-lived, from a few days to a few weeks. But journalists coverage of global warming did not fade as other crises did, and as a result, climate scientists were regularly sought for comment for updates on the slow crisis of climate change and its impacts on the environment, sea-level rise and human health.

The ongoing media attention that global warming received since the late 1980s was an important influence over the formation of international summits, beginning with the Rio Summit in 1992, that led to the establishment of the UNFCCC in 1994. Around the same time, the IPCC commenced its climate assessment reports (in 1989), which were then collated every six years.

In the $1990 \mathrm{~s}$, as a response to both the media attention and intergovernmental action to address climate change, fossil fuel interests recognized the danger that the science potentially 
posed to their profitability, and they began campaigns and alliances that would sow extensive doubt among the public. Suddenly, reporting had to be balanced and the voices of a powerful, corporately-funded climate denial industry were given attention across many media platforms.

Today, the purpose of almost all climate change communication (and misinformation) is to influence policy and action in some way, no matter how modest such influence is. The science and politics of climate change presuppose each other.

Wherever the communication of climate change is to be found, this nexus is self-evident. For example, scientific organizations with climate research departments will list their responsibility to communicate their science to governments, policy makers and the public. When NGOs communicate climate science to the public, their aim is to change voter intentions towards parties which have a political platform to take effective action on climate change. NGOs will devise entire campaigns that explain the science of climate impacts as well as the political policies needed to mitigate such impacts. Governments themselves today have departments of climate change and emissions reduction.

Yet, whilst the science and politics are so intertwined, in many developed nations like Australia, the US and Canada there is substantial political division on climate change, as discussed in Theme III of this volume. This division is found in the media and in audience segments, but also in the political will to act on climate change.

In the nineteenth century, sociologist Max Weber wrote two essays: 'Politics as a vocation' (Weber 1974a) and 'Science as a vocation' (Weber 1974b). Weber argued that, in secular societies, science replaced religious worldviews and that scientific progress had become a new telos. However, his paper on politics described how politicians were often torn between an ethic of conviction and an ethic of responsibility towards their constituents (Weber 1974a). This tension is still evident today in the twenty-first century, with politicians putting party ideology, often drawing on religious values, before the ethic of responsibility. The ethic of responsibility entails listening to experts who are able to guide politics to action towards a course that serves the public.

Remarkably, the best climate communication seems incapable of addressing the lack of political will to address climate change that is seen in some democracies. Even when progressive parties take power, the division impedes effective policy, creating a political inertia that cannot match the speed at which humans are changing the climate.

As Bill McKibben (2003, p. 12) has argued: 'The contrast between two speeds is the key fact of our age: between the pace at which the physical world is changing and the pace at which human society is reacting to this change.'

\section{LESSONS FROM THE CORONAVIRUS}

Here we come to the paradox of a monumental knowledge-action gap: the fact that climate change, the most important contemporary issue facing human beings and millions of other species, receives such an inadequate response.

As of the year 2020, if global $\mathrm{CO}_{2}$ emissions continue at current rates, we are on track to warm the world's climate by more than 4 degrees above pre-industrial levels by 2100 . This will commit the Earth to sea-level rise of 0.8-1.2 metres this century, and create superstorms incompatible with human infrastructure (IPCC 2013, pp. 1183, 1188). 


\section{Research handbook on communicating climate change}

With the pledges made by 195 countries in the Paris Climate Summit of 2015 (COP 21), the nationally determined contributions (NDCs) add up to 3 degrees Celsius of warming. What is needed to prevent dangerous climate change is to lower emissions enough to keep warming below 1.5 degrees Celsius.

In the face of this, in 2020 there are countries emitting the equivalent of four times the global average, and their politicians don't seem to care.

How can this state of affairs be explained?

One answer is to compare political responses to the climate crisis with responses to the global pandemic from the coronavirus in 2020 .

Here, there are many contradictions. The vast majority of governments around the world listened to medical scientists at the start of the pandemic. Scientists knew very little about the virus, yet politicians spent hundreds of billions of dollars on economic rescue packages on that basis (Galbraith \& Otto 2020). Conversely, for over three decades climate scientists have developed extensive knowledge of climate change that has been summarized so clearly for governments as to make inaction unthinkable. The medical scientists told us that 'every hour' is vital in fighting the virus, just as climate scientists tell us that every week has been vital in the critical decade that ended in 2020, and now the transformation decade to 2030.

There are several possible explanations for this inaction by politicians. One is that it is in the interests of politicians to solve COVID-19 within their current terms of office if they are to have any prospect of re-election, whereas they perceive climate change to be something future politicians will need to worry about decades from now.

Secondly, in cases where politicians identify with climate denial lobbies, they do not trust climate science, but will trust the medical profession as it is tied to a major campaign infrastructure known as the 'healthcare system'. Moreover, there are no vested industry interests sowing doubt about the reality of COVID-19, as there are for climate change.

Thirdly, climate change is marginalized as an environmental issue and not set within a health frame, where it would be on a continuum with something like a pandemic.

Finally, the media coverage of COVID-19 is focused on the immediate threat and spectacle of the death and infection count, the economic and social restrictions and politicians are responding to that coverage. Whereas the reporting of climate change as a slow crisis can be responded to by planning meetings, attending climate summits or waiting until other countries take action. Yet, ironically, there has been very little attention to how climate change itself is linked to COVID-19. The disruption of natural ecosystems by climate change, as well as terraforming, has increased the transfer of disease from wild species to humans and is a principal cause of the increase in occurrences of neglected, forgotten and new human diseases (Lorentzen et al. 2020). As climate change pushes natural reservoirs of viruses, such as bat colonies, poleward, new chains of human-animal contact and virus spillover emerge (Wang \& Anderson 2019).

Another link between COVID-19 and climate change is the fact that some of the concepts needed to understand the virus are applicable to climate change. Hansen and Sato (2020) have suggested that the 'delayed response' of impacts from contracting the virus (a matter of one week compared to decades for climate change); positive feedbacks (such as potential exponential transmission of the virus); overwhelmed health systems that are rendered helpless to save patients, and bending the curve downwards are all relevant. The task with climate change is to achieve an emissions curve that follows the low emissions pathway (RCP 2.6) as 
prescribed at the UNFCCC Paris Summit. This requires a lockdown of $\mathrm{CO}_{2}$ emissions rather than business-as-usual emissions.

Whilst COVID-19 had the potential to educate the public about climate change, the concepts are less important for politicians than the issue-involvement of media audiences, which is decisive in whether climate change becomes something that they need to respond to at all. Politicians will certainly prioritize whatever concerns people the most, if it is in their interests to do so.

Chapter 27 by Anneliese Depoux and François Gemenne in Theme VII of this Handbook suggests several reasons as to why people are more afraid of COVID-19 than they are of climate change. Although both are global crises that will affect developing countries disproportionately, the immediacy of the threat of contracting the virus 'personally' attracts more attention than the systemic nature of climate change. Contracting the virus is possible in as little as 15 minutes, whereas the slow-but-accelerating crisis of climate change may affect people over longer time-frames. News media are captivated by the daily figures and scorecards of new cases, hospitalizations and deaths in a way that is serialized, unlike the often less visible deaths from climate change - from more extreme heatwaves, fires, storms and floods. Ironically, the height of the first wave of the pandemic was in May 2020, which was also, globally, the warmest May on record in the history of observations (NOAA 2020). Compared to the virus, this fact barely even registered in the world's media, despite the fact that it is a worrying signal of accelerated global warming happening in a year without an El Niño.

Moreover, whereas a global pandemic has a likely lifecycle of one to two years, the committed warming caused by climate change will last for over 1000 years, essentially irreversible in time-scales that humans care about.

Nevertheless, in the US, the Climate Change in the American Mind study, conducted at the height of COVID-19, found that acceptance that climate change was happening and that is it human-caused were at historic highs - even though the same respondents reported hearing less about climate change in the media (Leiserowitz et al. 2020). It is difficult to assess whether or not this trend in US public perceptions was related to COVID-19 elevating attention to the importance of climate change as a global issue, which might also be said of the global scale of the anti-racism protests seen in 2020. Understanding audience issue involvement and how they react to the reporting of extreme events and political action is of key importance to climate change communication research.

\section{AUDIENCE RESEARCH}

For many, the heart of climate change communication is the problem of overcoming the political division in public perceptions of the science, impacts and responses to global warming. Climate change NGOs that attempt to communicate the science often believe that increased climate literacy can overcome such divisions, making it difficult for any party without an adequate climate policy to be elected into office, or retain office. But this approach, that the problem is about 'awareness' or that providing the public with more facts about an issue like climate change will translate into effective decision-making, has several flaws.

Firstly, this 'knowledge deficit' approach (Suldovsky 2017), which sees the problem of communication as a 'messaging' issue, assumes a homogeneous audience that will move to action with the right 'facts'. Many studies have shown that facts alone will not lead to more 
concern, or generate action to address climate change. Actually, for some audience segments, more factual information will only entrench a dismissive perception of climate change (Bain et al. 2012). Secondly, if factual climate messages are delivered by sources that are not trusted on climate, few will listen.

\section{TARGETED AUDIENCES}

Trust is important for understanding audiences, as it is a major part of how such audiences are formed in the first place. In mainstream media, audiences, 'are not ready-formed receptacles awaiting to be discovered' (Holmes 2005, p. 113) but are products of mass loyalty to certain media texts. Thus, broadcasters and publishers work at generating an audience that they can sell to advertisers, who will try and target them with a particular kind of product.

This idea of strategic or targeted communication is the default sense of communication and 'outreach' in organizational, strategic and marketing communication. The audience is conceived as demographic subsets of broader media audiences or a sectoral audience. For example, scientific environmental organizations will often limit their communication to sectoral 'end-users'. These invariably are demographic segments of the population. The end-users may be geographically defined, such as farming or peri-urban communities. But they can also be defined by standard population demographics like gender, race, age, religion, income, or as a societal sector such as business, government or community.

There are many studies that look at how to communicate climate change to such groups. They range from very specific audiences to those more broadly fitting the categories above. Some examples are studies that evaluate programmes of climate change communication to high school students (Flora et al. 2014), visitors to national parks (Monani et al. 2018; Thompson et al. 2013), local communities (Krygsman \& Speiser 2016), corporate leaders (Hoffman 2018), farmers (Morrison et al. 2018; Wilson \& Roderick 2018), policy makers (Black 2015; Kirchhoff et al. 2013; Mukherjee \& Howlett 2018) or political conservatives (Wolsko et al. 2016).

\section{UNDERSTANDING INTERPRETIVE COMMUNITIES}

As discussed above, targeted audiences are characterized as benefiting from particular climate messages and knowledges, as opposed to general media audiences. Audiences of mass media and popular social media are generally thought of as undifferentiated, and if at all divided, they are so along political lines. Thus, most orthodox audience polls, such as those conducted by news organizations, tend to be entirely binary in nature, including for climate change. These kinds of surveys seek to understand how important an issue climate change is for voters in terms of belief or disbelief, concern or dismissal, or support (or lack thereof) for a strong climate policy.

The problem with binary profiles, which are often used in election polling or by policy think tanks to rank the importance of issues to a population, is that they provide little information by which to develop a communication strategy. For example, simply knowing that 75 per cent of a sample 'believe climate change is happening' tells us little about the source of their belief. Is it based on a high level of climate literacy? Is it because this part of the sample believe that 
is what their status group believes? Is it an indication that they are already taking on adaptive or mitigative behaviours? Even if the survey enquired further to find out that only 55 per cent of the sample believed climate change is human-caused, does it mean that this group is taking effective action that responds to climate change? And is there a message that can motivate this group to make effective decisions on how to respond to climate change that can be delivered through just a few channels? To effectively establish a communications strategy for communicating climate science and its impacts, much more information is needed about potential audiences.

\section{SEGMENTATION PROFILING}

For over a decade, climate change communication research has been using a social marketing approach to understand audiences. This involves identifying clusters or segments of the audience where membership of those clusters is defined by a mix of variables including knowledge, values, emotion, behaviour, belief and concern, issue involvement, and policy preferences. (See Chapter 10 by Klas and Clarke in Theme III of this Handbook for a review of the importance of four psychological variables in particular: climate change beliefs, values and moral foundations, identity, and political ideologies.) In Theme VI of this volume, Detenber and Rosenthal (Chapter 22) provide a comprehensive review of segmentation studies around the world, so here I will simply contextualize the critical importance of segmentation analysis for the entire field of climate change communication research.

A good way to begin is with Harold Lasswell's general mass media model of communication which asks: Who says what, in which channel, to whom and with what effect? (Lasswell 1948, p. 178). Media audiences, whilst having low visibility, are at the centre of the circulation of meaning in societies of electronic assembly. As such, it is necessary to explore the way these audiences engage with messengers and messages via particular channels, and how they respond to communication events.

However, in the much critiqued Lasswellian 'process model' of communication (Lasswell 1948, p. 178), media audiences are thought to be passive, undifferentiated and homogeneously constituted by 'channels' as viewers, listeners and readerships, in relation to which, media texts are measured by whether they can successfully reach their audience. Failure of communication is therefore seen to be due to interference in the 'signal', a failure of the messenger to be clear with the message, or a defect in the receiver of the message. Critical traditions in media studies have challenged the 'process model' contention that the purpose of all communication is to reach an audience. Stuart Hall's (1980) encoding/decoding framework, a trajectory of cultural studies, argued that audiences decode media texts in a range of ways that seldom coincide with how these texts are encoded. For him there are dominant decodings, but also negotiated and oppositional decodings of a text. Hall's rejection of a media effects analysis and the 'hypodermic needle' model of media power gave way to the idea of an active audience, in which audiences divide into interpretive communities on particular issues.

To some extent, interpretive communities will negotiate meanings according to demographics of age, gender, class, race, and so on. But these demographics are only part of the story. The meaning of a message is not determined by the messenger or the message, but a complex interplay of how this meaning is framed though ideological values and beliefs. These frames may be so powerful that individuals within an audience may even make sense of scientific 
information through an ideological frame, something that is explored in Theme II of this volume, which examines climate change denial.

The centrality of audience segmentation research is that it is able to map the complex relationship between messages, meaning and the division of audiences around issue involvement. For this reason, climate change audience researchers have often used 'latent profile analysis', where several variables such as climate knowledge, values and beliefs are analysed and distinct but otherwise hidden (hence 'latent') groups emerge.

In the studies outlined by Detenber and Rosenthal (Chapter 22), there are Six Americas, Five Germanys, Six Indias, Seven Singapores, Four, Five and Six Australias, and Five Bangladeshs, Chinas, Indonesias, Nepals, Pakistans and Vietnams. In each country, a different mix of key variables results in variations of descriptors for audience segments. In America, there are the Alarmed, Concerned, Cautious, Disengaged, Doubtful and Dismissive. A Five Australias study found Alarmed, Concerned, Uncertain, Doubtful and Dismissive, where the Cautious and Disengaged categories have been replaced with one Uncertain category. The Five Germanys don't contain a Dismissive group, with Alarmed, Concerned Activists, Cautious, Disengaged and Doubtful. The differences between the categories across countries is also important. 'Concerned Activists' in Germany exhibit less concern than the 'Alarmed', as might be expected, they are more active with energy conservation. Whereas the 'Concerned' in Australia, have high concern but surprisingly little knowledge on climate change. Each of these studies increases our insights into climate change communication by joining these action-value segments to demographic or geographic variables.

In India, six groups were found, Informed, Experienced, Undecided, Unconcerned, Indifferent and Disengaged. A stand-out finding in India was that the Disengaged in rural settings (19 per cent) was almost double the number of Disengaged in urban areas (10 per cent). The Informed were the wealthiest of the six groups, the Experienced the most religious, and the Undecided tended to be middle income, educated men. The Indifferent were the least religious and the Disengaged were disproportionately rural women (Leiserowitz et al. 2013).

Just from the example of India, it is possible to see how invaluable latent profile analysis can be for communication campaigns and policy settings. It is why the segmentation model has far and away become the paradigm for understanding interpretive communities on climate change. As Chryst and colleagues (2018, p. 1111) observe, 'regardless of the population or exact number of segments, scholars around the world have found audience segmentation to be a valuable tool, whether for assessing current issue understanding, developing communication strategies, or developing new messages to advance dialogue and action'.

\section{MATCHING MESSAGES TO AUDIENCES}

One of the challenges revealed by segmentation analysis is that there are no universal message frames that work with all audiences. It is therefore necessary to customize messages to particular audiences (see Chapter 10 by Klas and Clarke in Theme III of this volume for an extensive review). Six segments may require six different messages, for example, but then there is further difficulty. Through which channel do you reach these segments? It is not likely that the segments are neatly separated into their own preferred channels of communication. Thus, further research is needed on the media consumption habits of each segment. 
Hine and colleagues (2018, p. 66) contend that audience segmentation helps with four strategic decisions: Who should be targeted? How to optimize messages and intervention programmes for each audience selected for targeting? How to ensure the messages and interventions reach selected audiences? and How to select messengers for each audience segment?

\section{Who Should Be Targeted?}

Audience segmentation research has the capacity to recommend audience priorities. Is it cost-effective or wise to target entrenched denialist segments? Or are disengaged or uncertain segments the easiest groups to appeal to?

Most of this research is aimed at pairing messages with segments, although some research has sought to evaluate the effectiveness of messages that might work with all segments, such as 'co-benefit' messaging (see Herrmann, Amelung, Fischer and Sauerborn, Chapter 28 in Theme VII, and Bain et al. 2016). This research looks at whether potential co-benefits of addressing climate change (such as economic or community-solidarity benefits) could motivate pro-environmental behaviour around the world for both those convinced and unconvinced that climate change is real.

Communicating scientific consensus has also been found to be effective across segments in many countries (Lewandowsky et al. 2013). Van der Linden and colleagues (2015b) maintain that it is a 'gateway belief'; once it is acknowledged by audiences, accepting the science and the importance of responding to climate change is strengthened.

\section{How to Optimize Messages and Intervention Programmes for Each Audience Selected for Targeting?}

Once segments of the audience are selected, communication strategies can match messages with the demographic, psychological and behavioural attributes of that group. For example, concerned groups may not actually engage in pro-mitigation behaviour as they do not understand the range of behaviour required. Segments which exhibit pro-environmental values may not necessarily be focused on climate change as a principal issue (Bernauer \& McGrath 2016).

Dickinson and colleagues (2013) have found that for conservative groups, discussing the impacts of climate change on animals other than humans, especially those for which the audience cares, can elicit a very powerful set of emotional responses, including empathy and compassion across a broader audience.

In the US context, some studies have shown that public health frames are also effective across all segments (Maibach \& Nisbet 2018, Myers et al 2012, and see Weathers, Mosher \& Maibach, Chapter 26 in Theme VII). However, Roser-Renouf et al. (2014) found that whilst the Alarmed, Concerned, Cautious and, to a lesser extent, the Disengaged largely perceived global warming to have negative effects on human health, the Doubtful and Dismissive largely thought global warming did not have a negative impact.

In Australia, Hine and colleagues (2016) segmented an Australian survey sample according to adaptation intentions, and found three groups, Alarmed (34 per cent), Uncommitted (45 per cent) and Dismissive (20 per cent). For the Dismissive group, 'avoiding direct reference to climate change and highlighting local impacts' was very effective (p. 10). Additionally, across all three segments, communication that involved 'specific adaptation advice and strong 
negative emotive content' (p. 10) was very effective. It was noted that emphasizing 'collective responsibility and financial impact' (p. 10) was not very useful.

In another Australia survey, Sherley et al. (2014) found that a Cautious group was more responsive to words and images such as 'nature, environment, weather, farmers and Australian rainforest' (p. 276) and, less so, children. Using guilt was not found to be effective.

\section{How to Ensure the Messages and Interventions Reach Selected Audiences?}

This is about using the right channels for each segment, insofar as segments are also divided by types of media. For example, the Uncertain segment may be viewers of commercial TV, or Dismissive groups may spend a large amount of time online. Research on the utility of social media over traditional forms of media suggests that such media is self-segmenting, with groups forming that actually mirror the latent segments evident in national contexts (Tandoc Jr \& Eng 2018). Thus, social media could be a way to reach certain segments, but is an arena in which such divisions are reinforced. Moreover, Schäfer (2012) has shown that the most expert and trusted sources on the science, climate scientists and scientific institutions, are largely absent in online exchanges about climate change and 'information' is often caught up in politicized debates.

In the US, Roser-Renouf and colleagues (2015) have analysed the optimal channels to reach the Six Americas. They found that with the Alarmed group, 'opinion leadership' could be established through more narrowly focused channels such as environmental magazines, email newsletters and social media postings by environmental and scientific organizations. With regards to communicating to those segments outside Alarmed and Dismissive, 'low involvement strategies' through methods that access a broad audience are likely to be most effective. A similar finding was returned in an Australian study that saw broad audience media, especially TV and current affairs, as the best channels for engaging Cautious audiences (Morrison et al. 2013).

For a health frame, Roser-Renouf and colleagues (2014) found that the most effective communication of the health risks associated with climate change would be through health organizations to doctors who then communicate that information to their patients.

More generally, the importance of using climate fiction, theatre, dance, documentaries, photography, art installations, VR games, art pieces and personal interaction is explored in Theme IX in this volume, and in Corbett and Clark (2018). The arts have an ability to communicate the vulnerability and sensitivity of climate issues that other channels may lack.

\section{How to Select Messengers for Each Audience Segment?}

Audience segmentation can identify the most trusted messengers, whether this is related to their expertise or shared values they may hold with particular audiences.

Celebrities may be trusted by some segments (Anderson 2011), but the 'climate sciencepolicy-celebrity arenas are highly contested, characterized by uncertain facts, disputed values and politicized alternatives for action' (Boykoff \& Goodman 2009, p. 405). One of the first Australian studies to look at targeting segments found that celebrities and radio hosts were particularly ineffective messengers to Cautious groups. There have also been studies of the effectiveness of climate scientists doing advocacy (Kotcher et al. 2017), and local government and community leaders as communicators (Krygsman \& Speiser 2016). 
In Australia, the Monash Climate Change Communication Research Hub has conducted several studies showing that, averaging across all audience segments, the most trusted sources on climate science and impacts are climate scientists, followed by farmers, firefighters and weather presenters (Holmes et al. 2017). However, the more locally identified such sources are, the more they are trusted, with the exception of farmers and firefighters who are seen to be at the 'frontline' of climate change. Farmers need to figure out how to grow our food and firefighters put out the firestorms threatening biodiversity and human communities alike.

In all these cases, it is a matter of finding which trusted groups are able to act as messengers for identified segments, and what are the best messages that can be conveyed at each moment of the communication process.

\section{THE CHALLENGES OF COMMUNICATING CLIMATE CHANGE}

From the context already introduced, it is evident that the 'problem' of communicating climate change is resolved by research into its challenges. The barriers are found in the nature of scientific and media cultures, the problem of divided audiences, and the political climates that have been broadly discussed. In a way, this entire Handbook is about those barriers. In this section I am going to outline how they are addressed in each theme of this Handbook. Here, I will not give a summary of each chapter in this volume, as one is already provided within each theme by its editors. However, I will conclude this introduction by summarizing the contribution of each theme to climate change communication research.

\section{Theme I: Science}

Theme I, 'Communicating climate science', edited by Simon Torok and Ailie Gallant, deals with the one of the first barriers of communicating climate change - the abstract and complex nature of climate processes. Confidence and certainty in climate science are determined by the complexity of the science, scientists' ability to translate this complexity for different kinds of end-users, and therefore understanding the confidence that audiences already have in climate science and climate scientists. From the science end of the communication process, confidence is limited by the quality and quantity of evidence, but the confidence a scientist has in their own explanation of the science can be influenced by their uncertainty of the education level, ideology and beliefs of the audience they are trying to reach.

Moreover, climate science is largely communicated in a specialized language that is directed towards peers. For non-specialists, much of the language is either obscure or takes on a different meaning. This is further complicated by the fact that there are many audiences beyond the de facto binary of science and public. The science needs to be filtered and translated differently for decision makers and planners, students and young people, and with general audiences, and differently with legacy versus social media. In addition, climate science can be confused with other atmospheric issues such as pollution and ozone concentrations. At the same time, good climate science communication needs to navigate the politicization, misinformation and confrontation that many face in learning about and accepting the science. 


\section{Theme II: Denial}

Theme II on 'Climate science denial', edited by John Cook, investigates the origins of climate denial and how it has gained influence well beyond its ability to produce evidence for its claims. There is an extensive account of the 'climate change countermovement' (CCCM) in the US, conservative think tanks, and astroturf front groups, who are amplified and echoed by an extensive network of conservative media, from mass to social media and the blogosphere. The United States is analysed as a paradigm case study for the development of this countermovement, which has since been exported to populist and right-wing political parties around the world.

The drivers behind the ideological and economic history of the American CCCM are charted in detail to show that such a movement has been supported by vested interests who identify politically with the Republican party. Ultimately, a strategy of framing climate change as a political issue, rather than one of health or science is the greatest obstacle to moving on to solutions.

The theme shows how a relatively small amount of misinformation can lead to considerable self-silencing amongst climate scientists and the public. Rhetorical strategies that project uncertainty about scientific concepts and methods, about whether policies are even needed to respond to such doubts, and the supposed risks this might cause to economic and social well-being, are surveyed. Fake experts, logical fallacies, demanding impossible levels of evidence, cherry picking, and conspiracy theories are at the frontline of contrarian techniques.

But for every strategy of denial there are counter-strategies. One of the most powerful responses is to close the 'consensus gap' in settings where the general public mistakenly believe that the scientific consensus on anthropogenic climate change is well below the global figure of 97 per cent of climate scientists. If the strength of this consensus is highlighted to the public, acceptance of many more aspects of climate science is able to follow. But also pointing to the strategies and techniques by which denialist groups have attempted to debunk the science can inoculate the general public against accepting misinformation. However, as the volume and speed of information increase, 'technocognitive' techniques, or monitoring misinformation, are also needed. These techniques may include the use of algorithms checking everything from newsprint to websites, moderation of reader comments and detecting disingenuous authors on social media.

\section{Theme III: Psychology}

Theme III is on 'The psychology of climate change communication' and edited by Kelly Fielding.

Across all kinds of climate change communication analysis, it is not surprising how many studies incorporate psychological perspectives. In order to evaluate the impact of communication on behaviour, psychological factors inevitably emerge. In the case of climate change, this is complicated by the broad range of actors, with the behaviour of consumers, governments and business all being relevant. Behaviour is further constrained by cultural influences, the built environment and the technology used in particular settings for transport, housing and food production. But the ontology of climate change is a global one, and behaviour change that is locally-framed ignores the global complexity, such as consuming goods produced around the world, and generating carbon miles in transport and processing. Making behaviour mean- 
ingful at local scales is a challenge, and this meaning is embedded in levels of climate literacy. Individuals, institutions and governments need to recognize the problem before solutions can be socially normed.

Thus, this theme also explores norm-based communication strategies that can cultivate pro-mitigation behaviour. Evaluation of such strategies delivers several recommendations beginning with the need to avoid communicating negative descriptive norms. Demonstrating that positive mitigation behaviour is approved of by others is effective, as is highlighting the consensus that exists between climate scientists and societal groupings on the need to act on climate change. Promoting the views of demographics that have more invested in climate mitigation behaviour is also important, as seen in recent student strikes around the world.

Identifying the origins of such investment in action across all groups in society is also important. To this end, this theme also has an analysis of four key psychological variables of audience segments - climate change beliefs, values and moral foundations, identity and political ideologies in such audience segments. It argues that messages need to be pitched at these unique attributes of the segments. Climate change belief may not necessarily be anthropogenic, and underlying values may be oriented towards conservational frames of the local environment, rather than 'biospheric' values about dangerous climate change. Core values may themselves be overdetermined by political forms of identity.

\section{Theme IV: Visualization}

Theme IV on 'Visualizing climate change', edited by Mike Schäfer, deals with the fact that the psychological distance of climate change is also a problem of visualization.

The theme examines visual representations by climate scientists, activists, artists and advertisers, as well as trends towards localizing visual imagery and examples that include augmented reality mobile applications and $3 \mathrm{D}$ visualizations. There is also a chapter on how news media use images in climate change stories and the 'media effect' of visuals on audiences.

As well as providing a brief overview of the cognitive role of visuals, this theme reviews the gaps in the geographical diversity of research on news visualizations of climate change, from the standpoint of content and discourse analyses. The volume of imagery identified was large (approximately 1 in 3 articles included visuals) and increasingly diverse images are being used in news reports.

The images are broken into two main and four less common categories. The most common forms are images of the consequences of climate change and of well-known individuals. The less common categories include infographics, images of the causes of climate change, depictions of untouched nature, and options for action. With research suggesting that the two most common categories of images have important limitations, this raises challenges for news media operating in today's competitive market. Additional research is recommended to increase the analysis of non-Western media and of novel visualizations such as memes, and to broaden the research approaches utilized and the fundamental conceptual status of news media imagery.

Media effects research on climate visuals has adopted mixed method, qualitative and quantitative approaches that are applied to a diverse range of visual genres, from still images found on websites and mass media, to game simulations. Audiovisual imagery is harder to research and had historically focused on short-term effects. Overall, emotional and behavioural 
response have been the main focus, with research that attempts to map the differences in the salience of images and the degree to which they support self-efficacy in audiences.

\section{Theme V: Reporting}

Theme V on 'Climate change reporting', edited by Elisabeth Eide and Risto Kunelius, begins with a strong overview of the challenges and opportunities of climate reporting.

The problem of navigating the discourses of science and politics discussed earlier in this introduction makes climate reporting one of the greatest tests of modern journalism. Journalists have a unique opportunity to make business and politics accountable on climate change whilst also responding to the increasing appetite news audiences have to explain the latest extreme weather event or anomalous trend. Another challenge is that the news industry is itself changing, with so many new media platforms fragmenting audience attention. This has, in turn, given rise to global initiatives amongst journalism professionals such as 'Covering Climate Now', for which 400 news outlets worldwide have pledged to improve their climate coverage. Of course, as extreme weather becomes more frequent around the world, news values have shifted and require more investigative and digital journalism that explains the science behind these events.

Extreme weather events are arguably the most important time to report on climate change, as the impact of the additional energy stored in our oceans and atmosphere, resulting from anthropogenic forcings, is made so much more visible and in a time-frame that coincides with news cycles. However, Extreme Event Attribution (EEA) studies are often catching up with that news cycle, and so the science does not make it into the stories, let alone the headlines, until the impact of the event has subsided. Moreover, the attribution studies are limited to calculating the likelihood of a particular event occurring more frequently or more intensely due to human-made climate change, which is harder to narrativize. But even this assumes that journalists have easy access to the science, have some training in climate science themselves and the time and space to devote their attention to attribution when the sheer 'emergency' drama of the event is calling them.

Whilst efforts to improve reporting are scaled up, an endemic feature of global reporting is the disproportionate attention given to the Global North. Inversely, the Global South - which is much more exposed to climate change whilst emitting far less greenhouse gases per capita - has many more stories to tell, with relatively few studies of what these stories are and how they compare on a global index of reporting. This inequality is but one of the measures of the broader problem of global climate justice. In this theme, two compelling case studies of Bangladesh and Uganda are provided. Climate reporting in the Global South is much more likely to explore South-North dependency and the UN Sustainability Development Goals than journalism in more developed countries.

So whilst climate change is a global problem, it is reported on very unevenly. With food security and the threat multipliers of climate change affecting developing countries so much more, it is notable that the stories to emerge from global climate events such as the IPCC Fifth Assessment Report in 2014 and COP 21 in Paris in 2015 show newspaper coverage of the large population countries of the South to be much smaller than coverage of smaller population countries of the North. 


\section{Theme VI: Campaigns}

Theme VI on 'Climate change communication campaigns' is edited by Lucy Richardson. Climate communication campaigns by NGOs are typically oriented towards pro-mitigation behaviour, and by government organizations, pro-adaptation. As already foreshadowed, this theme begins with an overview of audience profiling around the world using segmentation analysis. Understanding segments is a precondition of campaign message targeting.

But evaluating the effectiveness of such messages for each segment is also vital if such campaigns are to be improved. So, the theme also evaluates a campaign aimed at changing mobility behaviours using a stage model of self-regulated behaviour change, applied in a web-based decision support system known as BLAZE. Each of the model's four stages is outlined, alongside a review of studies that evaluated the model's effectiveness and also the effectiveness of the BLAZE support system's behaviour change campaign.

Bringing together theory and practice in climate communication campaigns is important, but too often, pro-mitigation campaigns from NGOs and governments lack the research guidance needed to be most effective. Featuring Australian case studies, this theme finds that having access to appropriate research resources and networks is critical. At the same time, researchers could improve support for campaigns by applying best practice communication when targeting practitioners, and by providing up-to-date assessments of attitudes, behaviours and media channel preferences of the audiences campaigns are trying to reach. Crucially, evaluation of the impact of messages for each audience is arguably the most important component of the research guidance, as it can inform a continuous cycle of improvement for similar future campaigns across government and NGO public education initiatives.

\section{Theme VII: Health}

Theme VII on 'Health communication of climate change', edited by Anneliese Depoux, addresses how public health frames can help address several of the psychological barriers that limit climate change action and engage the wider public. US studies show that public awareness of the health implications of climate change is low and adopting health frames can improve understanding of these risks. There are a range of health communication tools identified that are more likely to succeed when the global reality of climate change is related to local threats and experiences and promoting solutions that connect individual action with individual and community benefits.

The importance of the local is illustrated with a comparison of climate-related risks to health with the experience in 2020 with COVID-19. People were concerned with how the transmission of the virus would find its way to them personally and that vigilance would ensure the threat would pass. However, climate change is perceived to not have the same immediacy, and few understand that it is comparatively irreversible, and that this irreversibility needs to be addressed now.

Therefore, pricing health into climate solutions is very important in order for individuals to make the necessary sacrifices, which could be modest compared to those made for COVID-19. Often what may seem like a sacrifice is offset with a benefit. For example, decarbonization of the transport sector can radically reduce exposure to health-damaging air pollution. Promoting health co-benefits framing of climate change messages to householders and policy makers can be an effective way to overcome psychological barriers and effect behaviour change. 


\section{Theme VIII: Justice}

Theme VIII on 'Climate justice communication', edited by Anna Roosvall and Mathew Tegelberg, begins with a general account of the economic, cultural and political justice that shape the conditions of possibility for climate justice, particularly for indigenous communities.

The historical injustices of colonialism and industrial powers that have avoided accountability for the major share of greenhouse emissions in the Earth's atmosphere today, have shaped the international nature of climate politics. The spatial and temporal dimensions of globalization delimit the geographies of climate justice, as well as a neo-colonial bias towards the Global North in the reporting of climate impacts. For global climate justice to be realized, it must happen on all geographic scales: local, regional, intranational, international and transnational. Media reporting of climate realities can create a shared experience of a climate justice issue across scales, or at least transform local issues into transcendent or universal ones. The theme illustrates such reporting with studies covering many world regions that demonstrate a lack of consensus on how to represent climate justice, hindering the development of joint international action.

There is also a longer case study that is indicative of the state of climate justice reporting in Russia. With the land masses of the northern hemisphere warming at a far greater rate than the rest of the world, the vast continental forests and tundra of Northern Russia are highly exposed with instances of ancient diseases being released into active pathogen chains. Such is the case of an anthrax outbreak on the Yamal Peninsula in Russia, in relation to which climate change was largely excluded from media reports, even after the Yamal government had convened an international scientific meeting on preventing infectious diseases 'in times of climate change'. So, this theme explores why there is low interest in climate attribution reporting of unusual events such as the release of pathogens in a global warming hotspot. In the Russian case, adequate reporting of the Yamal incident would have supported regional grievances within Russia, and the demand for climate action in a major hydrocarbon state with diminished political and media freedoms.

\section{Theme IX: Climate Change Fiction}

Theme IX on 'Climate change fiction', edited by Roman Bartosch, takes on the power of the arts in climate change communication. The cli-fi novel, cinema, theatre and climate fiction pedagogy are each explored in a round-up of what such art forms can offer that science, politics and the media cannot.

The popularity of the cli-fi genre is explored. An orthodox reading of cli-fi, that it is to inspire action and increase climate literacy, is challenged by two perspectives that suggest cli-fi either helps the reader negotiate the trauma and the everyday pathologies of climate change, or helps build a kind of aesthetic adaptation to it.

Cli-fi is much older than media narratives about anthropogenic climate change, with tropes of geo-engineering being found in Jules Verne and early twentieth-century literature.

At a cognitive level, cli-fi can offer something that straight climate science cannot - ways of imagining a reality that is otherwise inaccessible to the human senses. But at an emotional level, cli-fi can also provide us with ways of processing the threat that climate change poses to us and the meaning of the actions we take towards it. 
The theme compares the relative influence of cinema to the novel, in terms of issue engagement. For example, the film The Day After Tomorrow was the highest grossing cli-fi film of all time. Viewers of the film did become much more engaged with climate change as a result, even if in a way that was confused by images of global cooling. However, there is a critical lack of audience research on these films. Since the earlier blockbusters of The Day After Tomorrow and the documentary An Inconvenient Truth, the number of cli-fi films has increased, but audience impact research has not.

Also on the increase is the number of cli-fi theatre productions around the world, some of which are sampled in this theme. Theatre is well-suited to the physical, political and ethical dramas of climate change. Whilst some aspects of climate change resist dramatic representation (such as scientific models, global and inter-decadal trends), others welcome it (like extreme weather, the ethics of accounting for one's own carbon footprint, and the political theatre of policy division).

The theme argues that all of these art forms define a new pedagogy around climate change as an ontology that expands well beyond the communication of the science. Each, for example, projects a power to overcome the ever-growing chasm of powerlessness of individual agency and the sublime physics of climate change. This involves recognizing the incommensurability of personal, national and global responses to climate change that can only be achieved within arts-based pedagogies that address intersectional politics of class, community and uneven climate impacts around the world.

\section{WRITING THE ANTHROPOCENE: COMMUNICATING ACROSS THE SCIENCES}

This Handbook assembles 45 leading climate change communication scholars from 39 universities and centres around the world, who have distilled an important analysis of the greatest challenge facing every nation on Earth. The authors come from a diverse range of disciplines and university departments, which is precisely what is needed to address the complexity of climate change. Within just a few decades, every university on Earth will have to transform itself to being a climate change university - just one of the forms of adaptation that will be needed. To adequately address climate change, the hard sciences and social sciences will need to talk to each other. The great many kinds of climate scientists dealing with oceans, ice, atmosphere and ancient climate, as well as economists, psychologists, sociologists, historians, political scientists, artists and geographers, will need to learn from each other to get the full context of what the Anthropocene actually means. This has started to happen with the assessment reports of the IPCC, which for decades only featured climate scientists.

Global cooperation from scientists, politicians and communication experts is needed to achieve so much in such a short time to educate the public about the scale of the challenge ahead.

With this volume, it is hoped that the relevance of all disciplines to climate change can be recognized in the breadth of the analysis, and communicating this relevance as much as the physical reality of the anthropogenic climate change will be vital in the decades ahead. 


\section{REFERENCES}

Anderson, A 2011, 'Sources, media and modes of climate change communication: The role of celebrities', WIREs Climate Change, vol. 2, no. 4, pp. 535-546.

Bain, PG, Hornsey, MJ, Bongiorno, R \& Jeffries, C 2012, 'Promoting pro-environmental action in climate change deniers', Nature Climate Change, vol. 2, pp. 600-603.

Bain, PG, Milfont, T \& Saviolidis, N 2016, 'Co-benefits of addressing climate change can motivate action around the world', Nature Climate Change, vol. 6, pp. 154-157.

Bernauer, T \& McGrath, LF 2016, 'Simple reframing unlikely to boost public support for climate policy', Nature Climate Change, vol. 6, pp. 680-683.

Black, R 2015, 'No more summaries for wonks', Nature Climate Change, vol. 5, pp. 282-284.

Boykoff, MT \& Goodman, MK 2009, 'Conspicuous redemption? Reflections on the promises and perils of the "celebritization" of climate change', Geoforum, vol. 40, no. 3, pp. 395-406.

Chryst, B, Marlon, J, van der Linden, S, Leiserowitz, A, Maibach, E \& Roser-Renouf, C 2018, 'Global warming's "Six Americas Short Survey": Audience segmentation of climate change views using a four question instrument', Environmental Communication, vol. 12, no. 8, pp. 1109-1122.

Cook, J, Oreskes, N, Doran, PT, Anderegg, WRL, Verheggen, B, Maibach, EW, Carlton, JS, Lewandowsky, S, Green, SA, Skuce, AG, Nuccitelli, D, Jacobs, P, Richardson, M, Winkler, B, Painting, R \& Rice, K 2016, 'Consensus on consensus: A synthesis of consensus estimates on human-caused global warming', Environmental Research Letters, vol. 11, no. 4. doi:10.1088/1748 $-9326 / 11 / 4 / 048002$.

Corbett, JB \& Clark, B 2018, 'The arts and humanities in climate change engagement', in MC Nisbet, SS Ho, E Markowitz, S O’Neill, MS Schäfer \& J Thaker (Eds), The Oxford Encyclopedia of Climate Change Communication Vol. 1, Oxford University Press, New York, pp. 48-66.

Dickinson, JL, Crain, R, Yalowitz, S \& Cherry, TM 2013, 'How framing climate change influences citizen scientists' intentions to do something about it', Journal of Environmental Education, vol. 44, no. 3, pp. $145-158$.

Flora, JA, Saphir, M, Lappe, M, Roser-Renouf, C, Maibach, EW \& Leiserowitz, AA 2014, 'Evaluation of a national high school entertainment education program: The Alliance for Climate Education', Climatic Change, vol. 127, no. 3, pp. 419-434.

Galbraith, E \& Otto, R 2020, 'Coronavirus response proves the world can act on climate change', The Conversation, 20 March. https://theconversation.com/coronavirus-response-proves-the-world-can-act -on-climate-change-133999.

Hall, S 1980, 'Encoding/decoding', in S Hall, D Hobson, A Lowe \& P Wills (Eds), Culture, Media, Language: Working Papers in Cultural Studies, Hutchinson, London, pp. 1972-1979.

Hansen, J \& Sato, M 2020, Bending the Curves, Climate Science, Awareness and Solutions, Columbia University, 14 April.

Hine, DW, Phillips, WJ, Cooksey, R, Reser, JP, Nunn, P, Marks, ADG \& Watt, SE 2016, 'Preaching to different choirs: How to motivate dismissive, uncommitted, and alarmed audiences to adapt to climate change?', Global Environmental Change, vol. 36, pp. 1-11.

Hine, DW, Phillips, W, Driver, A \& Morrison, M 2018, 'Audience segmentation and climate change communication', in MC Nisbet, SS Ho, E Markowitz, S O'Neill, MS Schäfer \& J Thaker (Eds), The Oxford Encyclopedia of Climate Change Communication Vol. 1, Oxford University Press, New York, pp. 66-94.

Hoffman, A 2018, 'Communicating about climate change with corporate leaders and Stakeholders' in MC Nisbet, SS Ho, E Markowitz, S O’Neill, MS Schäfer \& J Thaker (Eds), The Oxford Encyclopedia of Climate Change Communication Vol. 2, Oxford University Press, New York, pp. 1-23.

Holmes, D 2005, Communication Theory: Media, Technology, Society, Sage, London.

Holmes, D, Solano, N \& Hill, H 2017, A Survey of Australian TV Audience's Views of Climate Change, report, Monash Climate Change Communication Research Hub, Monash University, Melbourne.

IPCC 2013, Climate Change 2013: The Physical Science Basis. Contribution of Working Group I to the Fifth Assessment Report of the Intergovernmental Panel on Climate Change, Cambridge University Press, Cambridge and New York. 
Kirchhoff, CJ, Lemos, MC \& Dessai, S 2013, 'Actionable knowledge for environmental decision making: Broadening the usability of climate science', Annual Review of Environment and Resources, vol. 38, pp. 393-414.

Kotcher, J, Myers, T, Vraga, E, Stenhouse, N \& Maibach, E 2017, 'Does engagement in advocacy hurt the credibility of scientists? Results from a randomized national survey experiment', Environmental Communication, vol. 11, no. 3, pp. 415-429.

Krygsman, K \& Speiser, M 2016, Let's Talk Communities \& Climate: Communication Guidance for City and Community Leaders, ecoAmerica, Washington, DC.

Lasswell, H 1948, 'The structure and function of communication in society', in B Berelson \& M Janowitz (Eds), Reader in Public Opinion and Communication, 2nd edn, Free Press, New York, pp. 178-190.

Leiserowitz, A, Maibach, E, Rosenthal, S, Kotcher, J, Bergquist, P, Ballew, M, Goldberg, M, Gustafson, A \& Wang, X 2020, 'Climate change in the American mind: April 2020', Yale Program on Climate Change Communication, Yale University and George Mason University, New Haven, CT.

Leiserowitz, A, Thaker, J, Feinberg, G \& Cooper, D 2013, 'Global warming's six Indias', Yale Project on Climate Change Communication, New Haven CT. http://environment.yale.edu/climate- communication-OFF/files/Global-Warming-Six-Indias.pdf.

Lewandowsky, S, Gignac, GE \& Vaughan, S 2013, 'The pivotal role of perceived scientific consensus in acceptance of science', Nature Climate Change, vol. 3, pp. 399-404.

Lorentzen, HF, Benfield, T, Stisen, S \& Rahbek, C 2020, 'COVID-19 is possibly a consequence of the anthropogenic biodiversity crisis and climate changes', Danish Medical Journal, vol. 67, no. 5, article A205025.

Maibach, E \& Nisbet, M 2018, 'Communicating the public health risks of climate change', in MC Nisbet, SS Ho, E Markowitz, S O'Neill, MS Schäfer \& J Thaker (Eds), The Oxford Encyclopedia of Climate Change Communication Vol. 2, Oxford University Press, New York, pp. 279-294.

McKibben, B 2003, 'Worried? Us?', Granta 83: This Overheating World, vol. 83, pp. 8-12.

Monani, S, Principato, S, Dori, G \& Cooper, E 2018, 'Loving Glacier National Park online: Climate change communication and virtual place attachment', in W Filho, E Manolas, A Azul, U Azeiteiro \& H McGhie (Eds), Handbook of Climate Change Communication: Case Studies in Climate Change Communication Vol. 3, Springer International Publishing, Cham, pp. 63-85.

Monbiot, G 2006, Heat: How to Stop the Planet Burning, Allen Lane, London.

Morrison, M, Hine, DW \& D'Alessandro, S 2018, 'Communicating about climate change', in MC Nisbet, SS Ho, E Markowitz, S O’Neill, MS Schäfer \& J Thaker (Eds), The Oxford Encyclopedia of Climate Change Communication Vol. 2, Oxford University Press, New York, pp. 23-47.

Morrison, MD, Parton, KA \& Duncan, R 2013, 'Targeting segments in the Australian community to increase support for climate change policy', Australasian Marketing Journal, vol. 21, no. 4, pp. 212-217.

Moser, SC 2016, 'Reflections on climate change communication research and practice in the second decade of the 21 st century: What more is there to say?', WIREs Climate Change, vol. 7, no. 3, pp. 345-369.

Mukherjee, I \& Howlett, M 2018, 'Communicating about climate change with policymakers', in MC Nisbet, SS Ho, E Markowitz, S O’Neill, MS Schäfer \& J Thaker (Eds), The Oxford Encyclopedia of Climate Change Communication Vol. 2, Oxford University Press, New York, pp. 69-84.

Myers, TA, Nisbet, MC, Maibach, EW \& Leiserowitz, AA 2012, 'A public health frame arouses hopeful emotions about climate change', Climatic Change, vol. 113, no. 3-4, pp. 1105-1112.

National Oceanic and Atmospheric Administration 2020, Global Climate Report - May 2020. https:// www.ncdc.noaa.gov/sotc/global/202005.

Roser-Renouf, C, Maibach, E, Leiserowitz, A, Feinberg, G, Rosenthal, S \& Kreslake, J 2014, 'Global warming's six Americas, October, 2014: Perception of the health consequences of global warming and update on key beliefs', Yale University and George Mason University, Yale Project on Climate Change Communication, New Haven, CT.

Roser-Renouf, C, Stenhouse, N, Rolfe-Redding, J, Maibach, E \& Leiserowitz, A 2015, 'Engaging diverse audiences with climate change: Message strategies for global warming's six Americas', in R Cox \& H Anders (Eds), The Routledge Handbook of Environment and Communication, Routledge, New York, pp. 368-386. 
Schäfer, M 2012, 'Online communication on climate change and climate politics: A literature review', Wiley Interdisciplinary Reviews: Climate Change, vol. 3, no. 6, pp. 527-543.

Sheppard, K 2008, 'A voice in the wilderness', The Guardian, 24 June. https://www.theguardian.com/ commentisfree/2008/jun/23/climatechange.carbonemissions2.

Sherley, C, Morrison, M, Duncan, R \& Parton, K 2014, 'Using segmentation and prototyping in engaging politically-salient climate-change household segments', Journal of Non-profit and Public Sector Marketing, vol. 26, no. 3, pp. 258-280.

Shome, D \& Marx, S 2009, The Psychology of Climate Change Communications: A Guide for Scientists, Journalists, Educators, Political Aides, and the Interested Public, Center for Research on Environmental Decisions, New York. http://guide.cred.columbia.edu/pdfs/CREDguide full-res.pdf.

Suldovsky, B 2017, 'The information deficit model and climate change communication', Oxford Research Encyclopedias: Climate Science. doi:10.1093/acrefore/9780190228620.013.301.

Tandoc Jr, E \& Eng, N 2018, 'Climate change communication on Facebook, Twitter, Sina Weibo, and other social media platforms', in MC Nisbet, SS Ho, E Markowitz, S O'Neill, MS Schäfer \& J Thaker (Eds), The Oxford Encyclopedia of Climate Change Communication Vol. 1, Oxford University Press, New York, pp. 602-615.

Thompson, J, Davis, S \& Mullen, K 2013, 'Climate change communication campaign planning: Using audience research to inform design', The George Wright Forum, vol. 30, no. 2, pp. 182-189.

Tyndall, J 1861, 'On the absorption and radiation of heat by gases and vapours', Philosophical Magazine, vol. 22, no. 146, pp. 169-194.

Van der Linden, S, Maibach, E \& Leiserowitz, A 2015a, 'Improving public engagement with climate change: Five "best practice" insights from psychological science', Perspectives on Psychological Science, vol. 10, no. 6, pp. 758-763.

Van der Linden, S, Leiserowitz, A, Feinberg, G \& Maibach, E 2015b, 'The scientific consensus on climate change as a gateway belief: Experimental evidence', PLOS ONE, vol. 10, no. 2. doi:10.1371/ journal.pone.0118489.

Wang, LF \& Anderson DE 2019, 'Viruses in bats and potential spillover to animals and humans', Current Opinion in Virology, vol. 34, pp. 79-89.

Weber, M 1974a, 'Politics as a vocation', in From Max Weber: Essays in Sociology, trans. and ed. HH Gerth \& CW Mills, Routledge \& Kegan Paul, London, pp. 77-128.

Weber, M 1974b, 'Science as a vocation', in From Max Weber: Essays in Sociology, trans. and ed. HH Gerth \& CW Mills, Routledge \& Kegan Paul, London, pp. 129-158.

Wicks, F 2020, 'The engineer who discovered global warming', Mechanical Engineering, vol. 142, no. 3, pp. 36-41.

Wilson, B \& Roderick S 2018, 'Delivering solutions: engaging farmers and land holders in the climate change debate', in W Filho, E Manolas, A Azul, U Azeiteiro \& H McGhie (Eds), Handbook of Climate Change Communication: Practice of Climate Change Communication Vol. 2, Springer International Publishing, Cham, pp. 263-275.

Wolsko, C, Ariceaga, H \& Seiden, J 2016, 'Red, white, and blue enough to be green: Effects of moral framing on climate change attitudes and conservation behaviors', Journal of Experimental Social Psychology, vol. 65, pp. 7-19. 